\title{
In situ observations of trophic behaviour and locomotion of Princaxelia amphipods (Crustacea: Pardaliscidae) at hadal depths in four West Pacific Trenches
}

\author{
ALAN J. JAMIESON ${ }^{1}$, ANNE-NINA LÖRZ ${ }^{2}$, TOYONOBU FUJII ${ }^{1}$ AND IMANTS G. PRIEDE ${ }^{1}$ \\ ${ }^{1}$ Oceanlab, Institute of Biological and Environmental Science, University of Aberdeen, Main Street, Newburgh, Aberdeenshire, UK, \\ AB41 6AA, ${ }^{2}$ National Institute of Water \& Atmospheric Research (NIWA), 301 Evans Bay Parade, Wellington 6021, New Zealand
}

\begin{abstract}
The genus Princaxelia, Pardaliscidae, is a rarely recorded, infrequently collected and hitherto observed benthic amphipod, typically found at hadal depths $(>6000 \mathrm{~m})$ in the Pacific Ocean trenches. Little is known about the behaviour or physiology of this genus. Using a baited camera lander, observations of Princaxelia jamiesoni were made in the Japan Trench (7703 $\mathrm{m}$ ) and Izu-Ogasawara Trench $(9316 \mathrm{~m})$ and of Princaxelia aff. abyssalis in the Kermadec Trench $(7966 \mathrm{~m})$ and Tonga Trench $(8798 \mathrm{~m})$. These amphipods rapidly intercepted the bait and preyed upon smaller lysianassoid amphipods. Mean absolute swimming speeds for P. jamiesoni and P. aff. abyssalis were $4.16 \mathrm{~cm} . \mathrm{s}^{-1} \pm 1.8 \mathrm{SD}$ and $4.02 \mathrm{~cm} . \mathrm{s}^{-1} \pm 0.87 \mathrm{SD}$ respectively. These amphipods have the capacity for long range swimming, high manoeuvrability in close range, and efficient predatory behaviour. Burst swimming speeds for P. aff. abyssalis were 9 and $10 \mathrm{~cm} \cdot \mathrm{s}^{-1}$ with accelerations up to $22-25 \mathrm{~cm} \cdot \mathrm{s}^{-2}$.
\end{abstract}

Keywords: Princaxelia, Pardaliscidae, Amphipoda, in situ observations, trophic niche, hadal zone, Pacific Ocean

Submitted 22 November 2010; accepted 28 February 2011; first published online 19 April 2011

INTRODUCTION

In October 2008, several specimens of Princaxelia Dahl, 1959, Paradaliscidae, were recovered amongst hundreds of lysianassoid amphipods in baited traps at $7703 \mathrm{~m}$ in the Japan Trench (Figure 1). Similarly, in March of the following year, a further two specimens were recovered from $9316 \mathrm{~m}$ in the neighbouring Izu-Ogasawara Trench using the same equipment. The specimens were all described as Princaxelia jamiesoni Lörz 2010 by Lörz (2010).

The vehicle to which the traps were coupled was a free-fall $11,000 \mathrm{~m}$ rated video lander, known as Hadal-Lander A (Jamieson et al., 2009a), designed primarily to attract bait-attending fauna in view of a video camera. Upon recognizing the rarity of the presence of Princaxelia, the video footage from these deployments, and others from hadal depths in the western Pacific trenches, were revisited. Amongst swarms, often highly dense swarms of scavenging lysianassoid amphipods (typically Hirondellea spp.) footage of Princaxelia jamiesoni were found in both the Japan and Izu-Ogasawara Trench deployments. Furthermore, footage of what is believed to be Princaxelia abyssalis, Dahl, 1959 from $8170 \mathrm{~m}$ in the Kermadec Trench and $8798 \mathrm{~m}$ in the Tonga Trench (south-westPacific Ocean) were found.

There are currently four species of Princaxelia known to science: P. magna Kamenskaya, 1977; P. abyssalis Dahl, 1959; P. stephenseni Dahl, 1959; and P. jamiesoni Lörz,

Corresponding author:

A.J. Jamieson

Email: a.jamieson@abdn.ac.uk
2010. Princaxelia magna is known from a single male specimen of $52 \mathrm{~mm}$ from the Yap Trench (approximately $7300-$ $8500 \mathrm{~m}$; Kamenskaya, 1977) whereas $P$. abyssalis is known from eight of the west Pacific trenches (approximately 6500-9500 m; Kamenskaya, 1981; 1995). Princaxelia stephenseni is known from a single specimen from the south-east Pacific and three shallower specimens $(1505 \mathrm{~m})$ from the North Atlantic (Stebbing, 1888; Stephensen, 1931). More recently, Princaxelia jamiesoni was described from five specimens; three from the Japan Trench and two from the IzuOgasawara Trench at 7703 and $9316 \mathrm{~m}$ respectively (Lörz, 2010). Therefore with the exception Princaxelia stephenseni all other species of Princaxelia are, so far, considered to be endemic to hadal trenches. A synopsis of the genus Princaxelia is given in Lörz (2010).

With the exception of $P$. jamiesoni, no complete type material of Princaxelia is currently available (including habitus and all appendices) and no Princaxelia species has ever been described in full detail. Other than the type material publications, no other records of $P$. magna or P. stephenseni exist (see summary in Lörz, 2010). As a consequence of low numbers of few species there is little information available regarding the ecology, behaviour and physiology of the genus. The stomach contents of $P$. abyssalis from the Soviet 'Vityaz' expeditions were analysed by Kamenskaya (1981, 1995) who concluded it was a 'carnivorous' species. Kamenskaya (1984) hypothesized that Princaxelia was a nectobenthic predator. Lörz (2010) speculated that princaxelid amphipods could be a top predator in the hadal trench environments.

The genus Princaxelia is a rarely recorded or seldom collected benthic amphipod with a seemingly large geographical and bathymetric distribution. With the exception of just two 


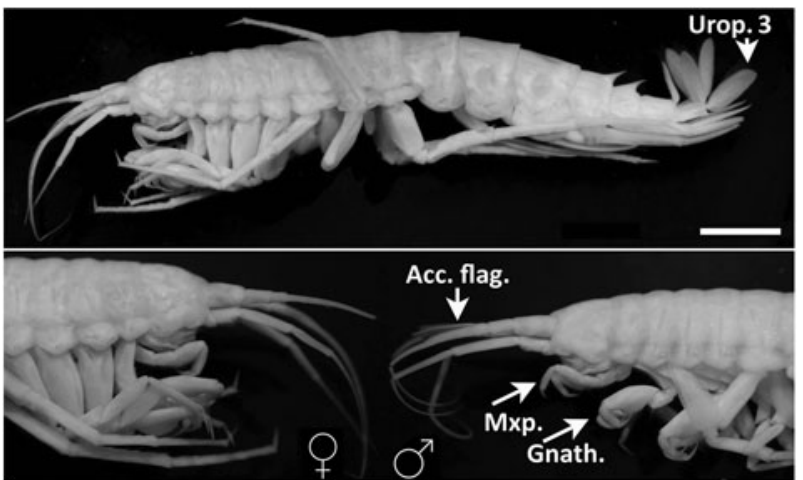

Fig. 1. Princaxelia jamiesoni (Lörz, 2010). Only males of Princaxelia have an enlarged accessory flagellum (Acc. flag.), both genders have long maxillipeds (Mxp.), strong gnathopods (Gnath.) and paddle shaped rami of uropod 3 (Urop. 3). Scale bar $=0.5 \mathrm{~cm}$.

specimens from the North Atlantic, all other specimens have been recovered from the hadal trenches of the west and North Pacific Ocean (Dahl, 1959; Kamenskaya, 1981; Lörz, 2010). Given the rarity of this genus and indeed as these are the only in situ moving images of the genus, reporting these observations provides an insight into the behaviour and physiology of these amphipods. Body size, general behaviour and locomotion of Princaxelia jamiesoni and $P$. aff. abyssalis are described here.

\section{MATERIALS AND METHODS}

\section{Baited camera system}

Video data were collected using Hadal-Lander A (Jamieson et al., 2009a). The lander, carrying a custom-built autonomous ${ }_{3}$ CCD video camera, was deployed by free fall to the seafloor unattached to the ship. It was pre-programmed to record one minute of video every 5 minutes in MPEG2 format $(704 \times$ 576 pixels, 800 TVL). The camera was positioned $1 \mathrm{~m}$ off the seafloor, with the camera and twin 50W lamps facing vertically down and focused on an area of seafloor $68 \mathrm{~cm} \times$ $51 \mathrm{~cm}\left(0.35 \mathrm{~m}^{-2}\right)$. A section of blue-fin tuna (Thunnus thynnus) was secured on a stainless steel bar in the centre of the field of view. A SBE-39 temperature and pressure sensor (Seabird Electronics, USA) recorded every 30 seconds throughout the deployment. Pressure data recorded in dbar were converted to depth (m) following Saunders (1981) and temperature $\left({ }^{\circ} \mathrm{C}\right)$ was averaged from the bottom data only. The lander's ascent to the surface was initiated by the jettison of ballast weights by acoustic command from the ship. On retrieval the data were downloaded. The lander was also equipped with 2-1 baited invertebrate funnel traps attached to each of the three feet. Invertebrate samples recovered were transferred to $99 \%$ ethanol.

\section{Study site}

To date, Hadal-Lander A has made ten deployments in, or on the edge of hadal trenches of the West Pacific Ocean (Japan, Izu-Ogasawara, Marianas, Kermadec and Tonga Trenches). Deployments which included observations of princaxelid amphipods are listed in Table 1.

\section{Data analysis}

Each video sequence was viewed and the presence of each amphipod in each sequence was noted and counted.

To measure body lengths (mid-trunk length; tip of rostrum to the end of the telson), frame grabs were exported from the video using image editing software (Studio 9, Pinnacle Systems Inc. USA). Measurements were made digitally using proprietary image analysis software (ImageJ $1.42 \mathrm{q}, \mathrm{NIH}$, USA). A calibration was set using the horizontal scale bar which secures the bait in the centre of the field of view. Upon landing, the scale bar often sinks below the sediment. Therefore a frame grab is taken from the last video sequence of the lander's descent for calibration.

Swimming speeds were analysed by selecting sequences in which an individual amphipod swam in a relatively straight line for more than 5 seconds. The sequence was extracted and deconstructed into frame grabs at 1 second intervals (every 25 frames). The frames were overlaid as layers in chronological order using Photoshop CS2 (Adobe Systems Inc., USA). On a transparent layer, a digital marker was placed at the anterior end of the amphipod between the antennae. After all the frame grabs had been marked, the digital markers were flattened into one layer against the first image and exported to ImageJ. Using the lander scale bar for calibration, the distance $(d ; \mathrm{cm})$ between each marker was measured. An additional measurement of body length of the individual being tracked was also taken (and added to the size-frequency data). The total distance travelled $(d ; \mathrm{cm})$ was divided by the time $(t ; s)$ to produce absolute speeds $(U$; $\mathrm{m} . \mathrm{s}^{-1}$ ) and then divided by the body length to convert to body length specific speed ( $U$; BL. ${ }^{-1}$ ). As swimming speeds were low, one-second frame grabs were the minimum that could achieve accurate measurements.

For sequences featuring burst swimming activity, the sequences were handled in the same manner but deconstructed into 0.2 seconds intervals ( 5 frames). The absolute speed $\left(U ; \mathrm{m} . \mathrm{s}^{-1}\right)$, size specific speed $\left(U ; \mathrm{L} . \mathrm{s}^{-1}\right)$, distance

Table 1. Details of the deployment sites where Princaxelia jamiesoni and P. aff. abyssalis were present. *, time lapse sequence $=1$ minute on, 4 minutes off.

\begin{tabular}{|c|c|c|c|c|c|c|c|c|}
\hline Trench & Date & Latitude & Longitude & $\begin{array}{l}\text { Pressure } \\
\text { (dbar) }\end{array}$ & $\begin{array}{l}\text { Depth } \\
\text { (m) }\end{array}$ & $\begin{array}{l}\text { Temp. } \\
\left({ }^{\circ} \mathrm{C}\right)\end{array}$ & $\begin{array}{l}\text { Number of video } \\
\text { sequences* }\end{array}$ & $\begin{array}{l}\text { Bottom time } \\
\text { (hh:mm) }\end{array}$ \\
\hline Japan & Sept. 2008 & $36^{\circ} 14.96 \mathrm{~N}$ & $142^{\circ} 49.01 \mathrm{E}$ & 7901 & 7703 & 1.9 & 77 & $06: 40$ \\
\hline Izu-Ogasawara & Mar. 2009 & $27^{\circ} 20.99 \mathrm{~N}$ & $143^{\circ} 18.89 \mathrm{E}$ & 9586 & 9316 & 2.2 & 38 & $03: 05$ \\
\hline Kermadec & Jul. 2007 & $26^{\circ} 54.96 \mathrm{~S}$ & $175^{\circ} 30.73 \mathrm{~W}$ & 8170 & 7966 & 1.5 & 117 & $10: 07$ \\
\hline Tonga & Jul. 2007 & $24^{\circ} 08.07 \mathrm{~S}$ & $175^{\circ} 10.95 \mathrm{~W}$ & 9036 & 8798 & 1.6 & 105 & $10: 05$ \\
\hline
\end{tabular}

Temp., temperature; Sept., September; Mar., March; Jul., July. 
travelled $(d ; \mathrm{cm})$ and acceleration $\left(a ; \mathrm{m} . \mathrm{s}^{-2}\right)$ were calculated as above.

Body length related regression analysis was performed using SPSS (SPSS Inc., USA).

\section{RESULTS}

Princaxelid amphipods were observed in situ in four hadal trenches: the Japan $(7703 \mathrm{~m})$, the Izu-Ogasawara Trench $(9316 \mathrm{~m})$, the Kermadec Trench $(7966 \mathrm{~m})$ and the Tonga Trench $(8798 \mathrm{~m})$. Examples of these data are shown in Figure 2.

In the Japan Trench, 77 one-minute sequences were recorded over 6 hours and 40 minutes on the seafloor. In the Izu-Ogasawara Trench the camera recorded 38 oneminute sequences spanning 3 hours 5 minutes on the seafloor. In the Kermadec and Tonga Trenches, the camera recorded over 100 sequences over approximately 10 hours on the seafloor. Location details and in situ temperature, pressure and corrected depths are shown in Table 1.

The sediment surface observed in the Japan Trench deployment was light siliceous ooze more typical of abyssal plains whereas despite a similar appearance, the sediment was extremely soft in the Izu-Ogasawara Trench. As a result of such soft sediment, the entire lander and bait sank to an estimated $10 \mathrm{~cm}$ below the sediment surface until the bait was no longer visible after 40 minutes which resulted in little or no activity observed after 1 hour 30 minutes. The sediments in the Kermadec and Tonga Trenches were dark brown and firm as no sinking of the lander was observed after 10 hours on the seafloor.

\section{Body size}

The body lengths of four individual $P$. jamiesoni were measured from the $7703 \mathrm{~m}$ deployment and four from the $9316 \mathrm{~m}$ deployment (Figure 3). At $7703 \mathrm{~m}$ their body lengths were relatively large $(57-71 \mathrm{~mm}$; mean $=65 \mathrm{~mm} \pm$ $6 \mathrm{SD})$ compared to that in the $9316 \mathrm{~m}$ site $(25-32 \mathrm{~mm}$; mean $=29 \mathrm{~mm} \pm 3 \mathrm{SD})$. In the Kermadec Trench the

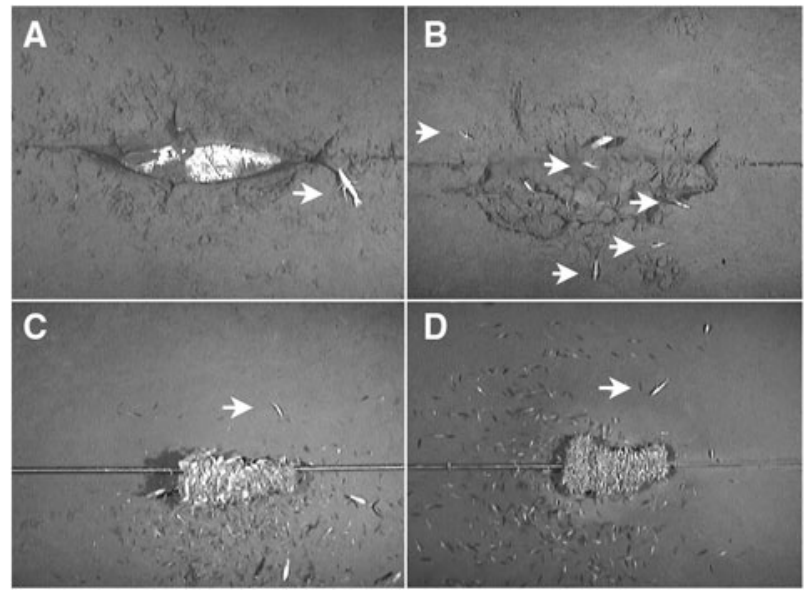

Fig. 2. Frame grabs from the video footage of Princaxelia amphipods indicated by white arrow at (A) $7703 \mathrm{~m}$ in the Japan Trench, (B) $9316 \mathrm{~m}$ in the Izu-Ogasawara Trench, (C) $7966 \mathrm{~m}$ in the Kermadec Trench and (D) $8798 \mathrm{~m}$ in the Tonga Trench. range of body lengths for $P$. aff. abyssalis was $19-51 \mathrm{~mm}$ (mean $=29 \mathrm{~mm} \pm 8 \mathrm{SD}, \mathrm{N}=14$ ) and in the Tonga Trench they ranged from $18-37 \mathrm{~mm}($ mean $=28 \mathrm{~mm} \pm 5 \mathrm{SD}, \mathrm{N}=$ 14).

The specimens caught in the traps at $7703 \mathrm{~m}$ in the Japan Trench were $56.2 \mathrm{~mm}$ (female; holotype), $57.5 \mathrm{~mm}$ (male; paratype) and $61.0 \mathrm{~mm}$ (female; paratype). At $9316 \mathrm{~m}$ in the Izu-Ogasawara Trench, the catch included one female at $36 \mathrm{~mm}$ and one $24 \mathrm{~mm}$ long juvenile.

\section{Behavioural observations}

At $7703 \mathrm{~m}$ in the Japan Trench, P. jamesoni arrived at 15 minutes (Figure 4). The footage was dominated primarily by the snailfish Pseudoliparis amblystomopsis (Liparidae) and large scavenging lysianassoid amphipods (Fujii et al., 2010). Six observations of individual $P$. jamieson $i$ were made periodically over 5 hours 10 minutes. The Izu-Ogasawara deployment recorded mostly amphipods which were too small in size to identify from the video footage but based on the trap samples were assumed to be mostly Hirondellea gigas (personal communication, N. Kilgallen, NIWA, NZ). Amongst the $H$. gigas there were several of the larger pardaliscoid amphipod Princaxelia jamiesoni with a first arrival time of again, 15 minutes. They increased in numbers to a maximum of five at 1 hour thereafter decreasing sharply when the bait became submerged into the soft sediment. A further two individuals were observed later on at 2 hours 55 minutes over three sequences.

The footage from the Kermadec Trench and Tonga Trench at 8170 and $8798 \mathrm{~m}$ respectively were dominated by very dense swarms of the scavenging amphipod Hirondellea dubia, as confirmed by the trap catch (personal communication, T. Horton, NOCS, UK). At $8170 \mathrm{~m}$ the first $P$. aff. abyssalis arrived at 41 minutes whereas the first $P$. aff. abyssalis arrival at $8798 \mathrm{~m}$ was 31 minutes. At both sites these amphipods were consistently present throughout the deployment reaching maximum numbers of two and three respectively. Their numbers did not appear to increase or decrease in response to the consumption of the bait by $H$. dubia.

In all four deployments neither Princaxelia species showed any direct interest in the bait itself, but rather they positioned themselves directly on the seafloor in no particular orientation to the bait. In the Izu-Ogasawara Trench, Kermadec Trench and Tonga Trench deployments there were instances of an individual rapidly lunging forward to attack a smaller scavenging amphipod. Although the resolution of the camera did not permit an accurate identification of the prey species, it was apparent that the Princaxelia were preying upon these smaller amphipods.

\section{Locomotion}

One large individual of $P$. jamiesoni at $7703 \mathrm{~m}$ in the Japan Trench had an absolute overground swimming speed of between 3.3 and $7.0 \mathrm{~cm} . \mathrm{s}^{-1}$ (mean $=5.4 \mathrm{~cm} . \mathrm{s}^{-1} \pm 1.79 \mathrm{SD}$ ) whereas the smaller individuals at $9316 \mathrm{~m}$ were $2.2-$ $3.6 \mathrm{~cm} . \mathrm{s}^{-1}$ (mean $=2.4 \mathrm{~cm} . \mathrm{s}^{-1} \pm 0.70 \mathrm{SD}$ ) (Figure 5). By conversion to body lengths per second (BL.s-1) this equates to $0.5-1.1$ BL.s ${ }^{-1}$ (mean $=0.73$ BL.s $\left.{ }^{-1} \pm 0.20 \mathrm{SD}\right)$ and $0.7-1.4$ BL.s ${ }^{-1}$ (mean $=1.00$ BL. $s^{-1} \pm 0.32$ SD) respectively. No significant relationship between body size and absolute swimming speed $\left(\mathrm{R}^{2}=0.445, \mathrm{~F}=4.812, P=0.071\right)$ or body 
A

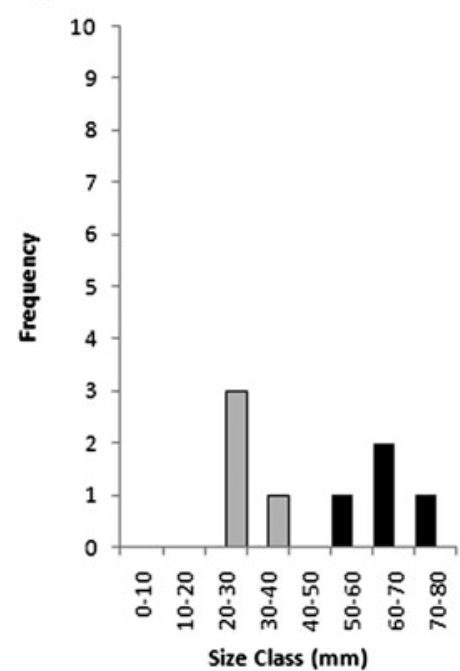

B

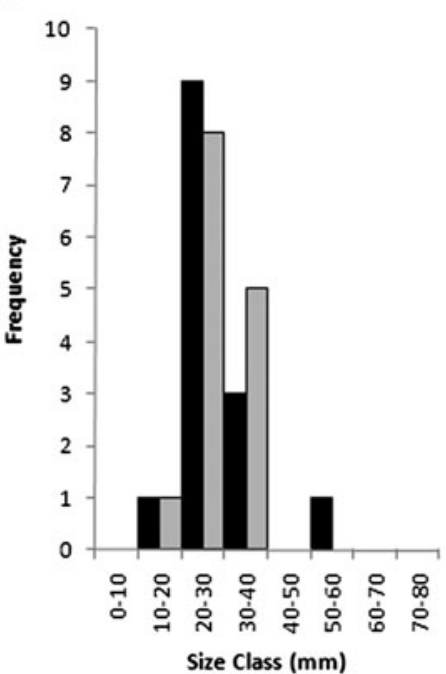

C

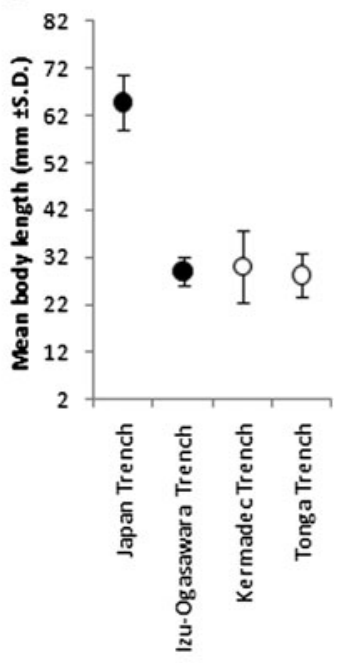

Fig. 3. (A) Size-frequency of the amphipod Princaxelia jamiesoni from the Japan Trench ( $7703 \mathrm{~m}$; black; mean $=65 \mathrm{~mm} \pm 6 \mathrm{SD}, \mathrm{N}=4)$ in the Izu-Ogasawara Trench $(9316 \mathrm{~m}$; grey; mean $=29 \mathrm{~mm}+3 \mathrm{SD}, \mathrm{N}=4)$; (B) size-frequency of Princaxelia aff. abyssalis from the Kermadec Trench $(7966 \mathrm{~m}$; black, mean $=$ $29 \mathrm{~mm} \pm 8 \mathrm{SD}, \mathrm{N}=14)$ and the Tonga Trench ( $8798 \mathrm{~m}$; grey, mean $=28 \mathrm{~mm} \pm 5 \mathrm{SD}, \mathrm{N}=14)$; (C) summary of mean body lengths of the two species from the four stations.

length with specific swimming speed $\left(\mathrm{R}^{2}=0.338, \mathrm{~F}=3.067\right.$, $P=0.130$ ) were found. The $P$. aff. abyssalis at $7966 \mathrm{~m}$ had an absolute over-ground swimming speed of between 2.5 and $4.0 \mathrm{~cm} . \mathrm{s}^{-1}\left(\right.$ mean $\left.=3.4 \mathrm{~cm} . \mathrm{s}^{-1} \pm 0.49 \mathrm{SD}\right)$ whereas at $8796 \mathrm{~m}$ were $4.4-5.2 \mathrm{~cm} . \mathrm{s}^{-1} \quad\left(\right.$ mean $=4.9 \mathrm{~cm} . \mathrm{s}^{-1} \pm 0.33$
SD). These convert to $0.9-1.2$ BL.s $^{-1} \quad($ mean $=1.06$ BL.s $\left.{ }^{-1} \pm 0.10 \mathrm{SD}\right)$ and 1.0-1.2 BL.s $^{-1} \quad($ mean $=1.10$ BL. ${ }^{-1} \pm 0.07$ SD) respectively. No significant relationship between body size and specific swimming speeds was found $\left(\mathrm{R}^{2}=0.001, \quad \mathrm{~F}=0.007, \quad P=0.937\right)$, however body size
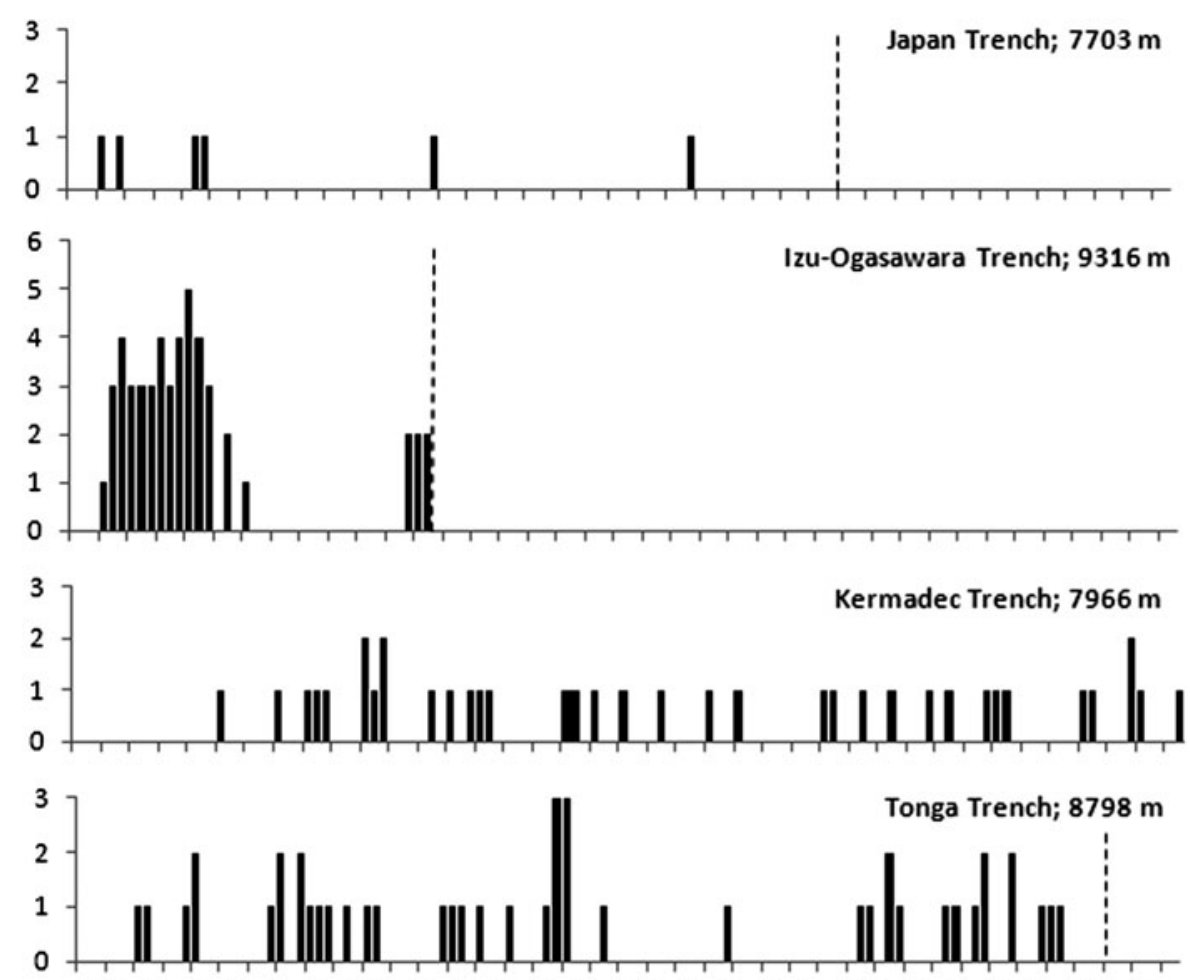

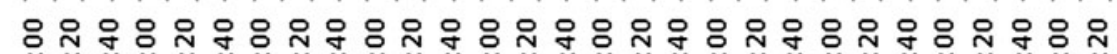

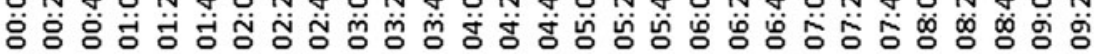

Time (hh:mm)

Fig. 4. The number of Princaxelia jamiesoni observed at the baited lander in the Japan and Izu-Ogasawara trenches and Princaxelia aff. abyssalis in the Kermadec and Tonga trenches. The dashed line represents end of filming. 
A

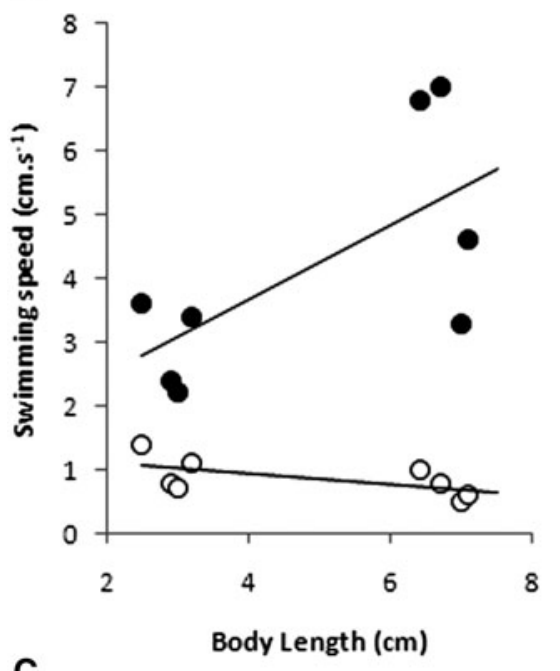

C

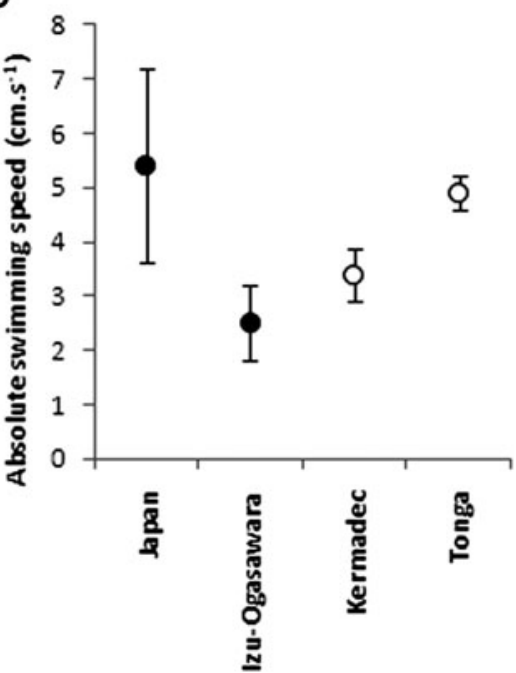

B

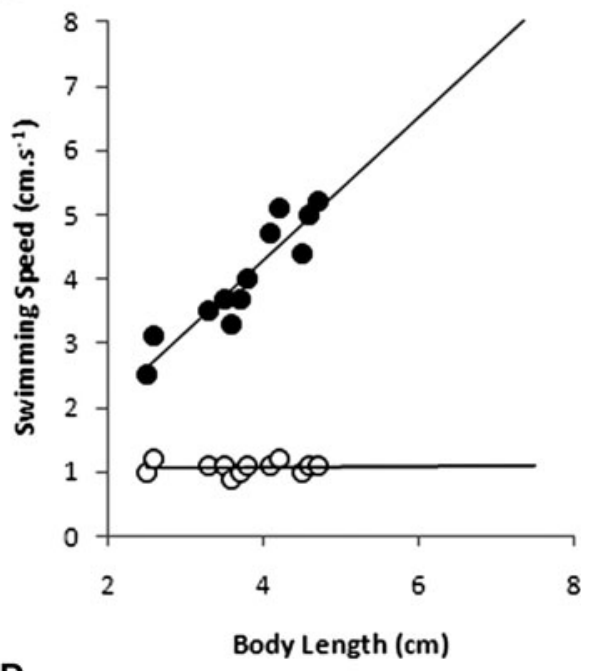

D

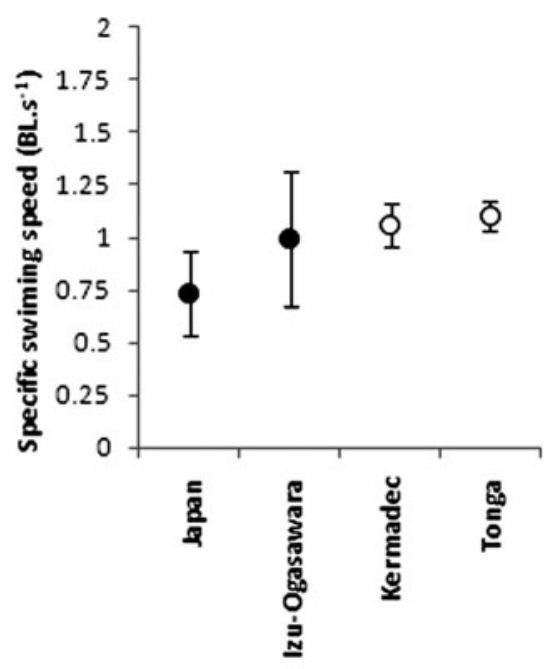

Fig. 5. Swimming speeds of Princaxelia amphipods. (A) Absolute overground swimming speed (closed dots) and size-specific swimming speeds (open dots) of the amphipod Princaxelia jamiesoni from the Japan and Izu-Ogasawara Trenches (7703 $\mathrm{m}$ and $9316 \mathrm{~m}$ respectively); (B) absolute overground swimming speed (closed dots) and size-specific swimming speeds (open dots) of the amphipod Princaxelia aff. abyssalis from the Kermadec and Tonga Trenches (7966 m and $8798 \mathrm{~m}$ respectively); (C) a summary of mean absolute swimming speeds $\left(\mathrm{cm} . \mathrm{s}^{-1}\right.$ ) for P. jamiesoni (closed dots) and P. aff. abyssalis (open dots); (D) a summary of mean specific swimming speeds (BL.s ${ }^{-1}$ ) for $P$. jamiesoni (closed dots) and $P$. aff. abyssalis (open dots).

versus absolute swimming speed was significant $\left(\mathrm{R}^{2}=0.859\right.$, $\mathrm{F}=60.713, P<0.0001)$.

The overground swimming gait of Princaxelia is somewhat awkward but highly manoeuvrable (Figure 6). During periods of overground locomotion individuals swam very close to the seafloor whilst trailing pereopods V-VII outwardly to the rear which maintained contact with the seafloor while gently beating their urosome. The pereopods V-VII were periodically extended perpendicular to the body against the seafloor for stability, particularly if changing direction. The dactylus of pereopod VI touched the sediment furthest away from the body, while pereopod VI was stretched nearly 90 degrees off. Pereopod VII touched the ground at about 75 degrees to the pleon. Before a direction change only one side of the pereopods touched the ground; only the left pereopods V-VII where extended when turning left (with the right pereopods trailing behind) and the opposite occurred when turning right. During swimming and in particular during direction changes the entire body flexes laterally in a 'fish-like' fashion, in fact its entire body and pereopods V-VII appear extremely flexible (see Figure 6). This combination of body flexing and pereopod stabilizing resulted in rapid direction changes and tight manoeuvres.

In the $7703 \mathrm{~m}$ deployment, there were two instances where P. jamiesoni, exited the field of view vertically. It did so by orientating the body vertically and swam upwards using a combination of rapid pleopod beating and beating of its urosome. The uropods were spread, while the wide paddle shaped rami of the third uropod created a fan-like structure. Due to the orientation of the camera it was not possible to obtain accurate vertical swimming speeds. During short periods of filming it was noticed that, when rising off the seafloor, these amphipods are capable of swimming on with an inverted posture, ventral side upwards.

Also observed in the footage of these amphipods was predatory behaviour. Whilst the larger P. jamiesoni at $7703 \mathrm{~m}$ were not seen to prey on anything, they did exhibit search behaviour whereby they approached the indentations on the seafloor left by the lander bait arm, and lowered their head into it as if searching. However, the other three deployments 

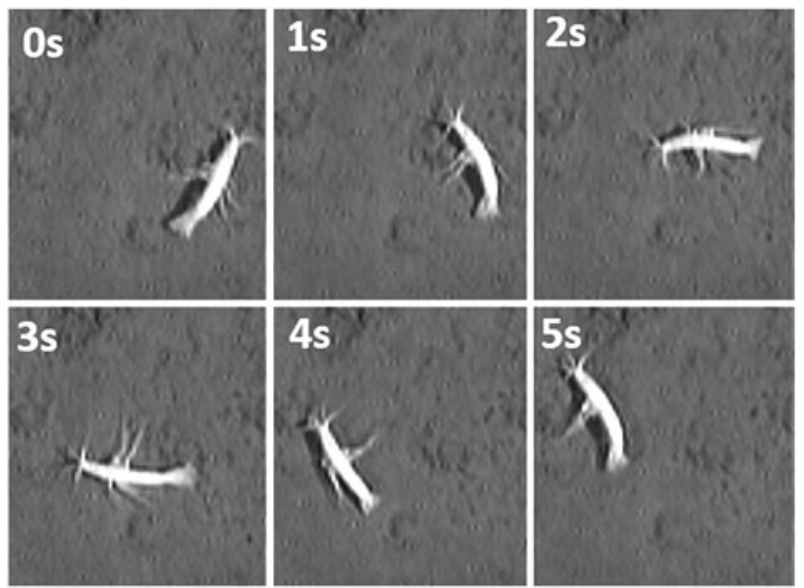

Fig. 6. Video frame grabs at 1 second intervals of Princaxelia jamieson swimming overground at $7703 \mathrm{~m}$ in the Japan Trench. The body is flexed to make tight turns whilst aided by its pereopods for stabilizing.

captured actual predatory attacks. Most attacks were of such a high speed over such a short distance that no accurate speed and acceleration data could be obtained with the exception of two attacks by $P$. aff. abyssalis at the Kermadec Trench site.

Both attacks lasted less than 2 seconds and comprised a rapid acceleration towards a small amphipod followed by a rapid deceleration (Figure 7). During the initial burst, speeds of 9 and $10 \mathrm{~cm} \cdot \mathrm{s}^{-1}$ were reached, equating to specific speeds of 1.8 and $2.8 \mathrm{BL} . \mathrm{s}^{-1}$. The acceleration reached up to $22-25 \mathrm{~cm} . \mathrm{s}^{-2}$, equalling 5 and $6 \mathrm{BL} \cdot \mathrm{s}^{-2}$. On these two occasions the small prey amphipod was no longer visible and although the camera resolution is insufficient to ascertain a direct kill, it appeared that the prey amphipod was being constrained by $P$. aff. abyssalis under its ventral surface using its elongated maxilliped and gnathopds. There were many instances of $P$. jamiesoni in the Izu-Ogasawara Trench and some of $P$. aff. abyssalis unsuccessfully attempting to capture prey.

\section{DISCUSSIDN}

These in situ observations and the specimens caught in the traps confirm the assumptions made by Kamenskaya (1981) and Lörz (2010) that princaxelid amphipods have welldeveloped olfactory senses, are carnivores and efficient swimmers. Bait interception times of between 15 and 41 minutes are relatively fast compared to other taxa at similar depths (e.g. decapods and fish; Jamieson et al., 2009b, c; Fujii et al., 2010). It is assumed that olfaction is the primary detection sense as princaxelid amphipods, particularly in the Japan and Izu-Ogasawara Trenches, arrived long before the other
A

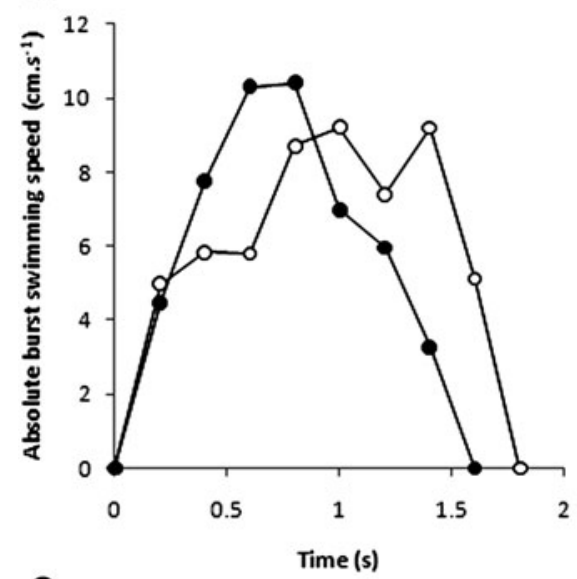

C

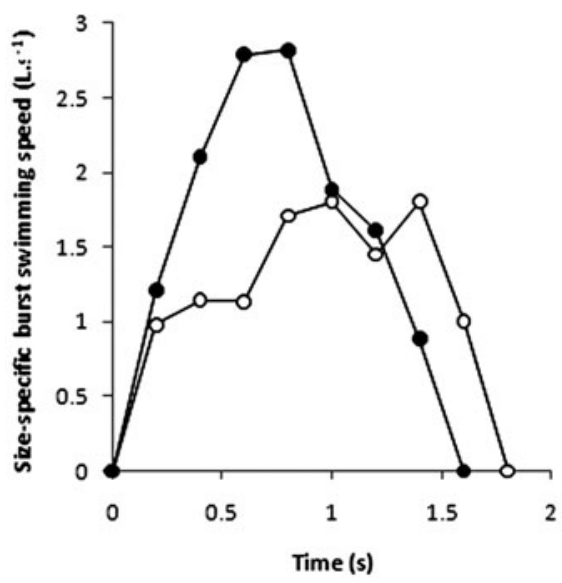

B
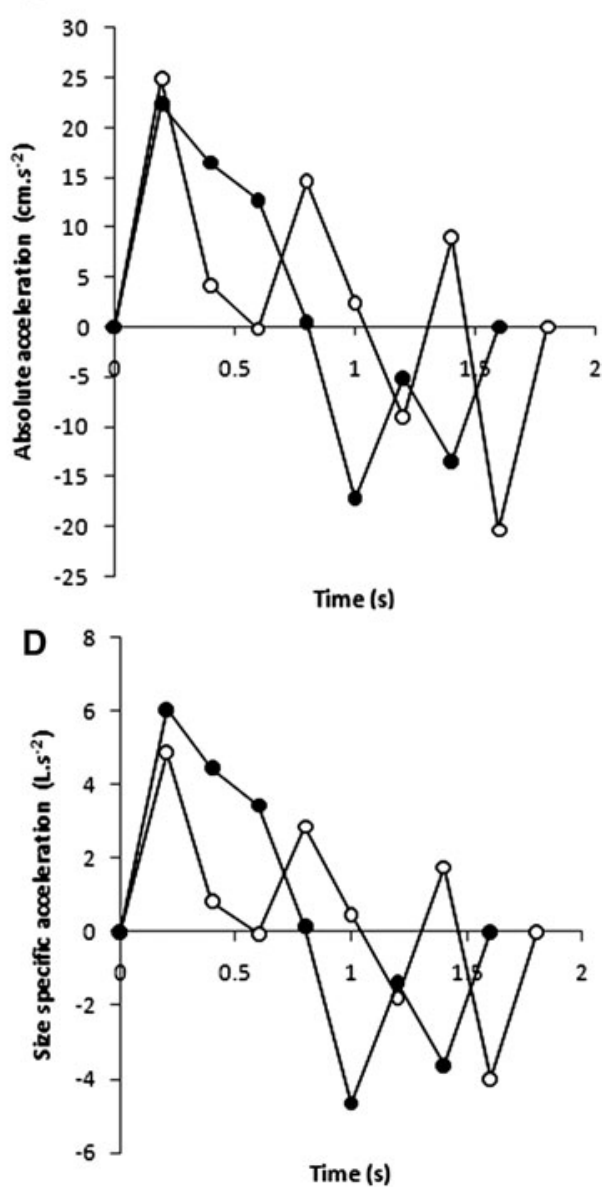

Fig. 7. Absolute burst swimming speed and acceleration (A-B) and size-specific burst swimming speed and acceleration (D-C) of the amphipod Princaxelia aff. abyssalis at $7966 \mathrm{~m}$ in the Kermadec Trench. 
amphipod species (mainly lysianassoids) aggregated in large numbers. Their status as carnivorous can be expanded further to confirm that they are not scavengers but rather predatory and prey on small scavenging amphipods; a common strategy at these depths (e.g. liparid fish and natatian decapods; Jamieson et al., 2009b, c).

Generally, Princaxelia exhibits impressive mobility and flexibility in swimming, not only forward in the typical horizontal posture but also backwards with the head up swimming vertically. As suggested by Lörz (2010) Princaxelia have an optimum body shape for efficient swimming as the telson and uropods can be hydrodynamically streamlined to reduce drag therefore increasing locomotive efficiency. In the case of $P$. jamiesoni the wide rami of uropod III can be used for routine locomotion and burst acceleration particularly useful during fast predatory attacks; a strategy all the more efficient given their strong mouthparts which can enable rapid immobilization of prey. Efficient swimming abilities is a trait known in other pardaliscid amphipods in the deep sea (Kaartvedt et al., 1994) where individuals were observed holding station in mid-water in current speeds up to $10 \mathrm{~cm} . \mathrm{s}^{-1}\left(>_{10} \mathrm{BL} . \mathrm{s}^{-1}\right)$.

Amphipod swimming speeds in shallow water range from 4.4 to $13.6 \mathrm{~cm} . \mathrm{s}^{-1}$ (Sainte-Marie, 1986). The swimming speeds of deep sea lysianassoids have been reported as $2.5 \mathrm{~cm} . \mathrm{s}^{-1}$ for Paralicella caperesca and $3.1 \mathrm{~cm} \cdot \mathrm{s}^{-1}$ for Orchomene sp. (Smith \& Baldwin, 1982). The most documented amphipod from deep waters is Eurythenes gryllus, an apparently cosmopolitan scavenging lysianassoid amphipod capable of swimming between 2 and $12 \mathrm{~cm} . \mathrm{s}^{-1}$ or 2.7 and $8 \mathrm{~cm} . \mathrm{s}^{-1}$ (Laver et al., 1985; Takeuchi \& Watanabe, 1998) for body lengths between 2 and $12 \mathrm{~cm}$. General comparisons between different species of amphipods are confounded by the fact these studies are of scavengers which may well be in an excited state when in the vicinity of bait and thus probably represent upper limits (Lever et al., 1985; Sainte-Marie \& Hargrave, 1987). For convenience, Lever et al. (1985) state a mean value of $7.3 \mathrm{~cm} . \mathrm{s}^{-1}$ for E. gryllus whereas Sainte-Marine \& Hargrave (1987) state a practical value of $5 \mathrm{~cm} . \mathrm{s}^{-1}$ for lysianassoids. The genus Princaxelia mean absolute swimming speeds measured via $P$. jamiesoni and $P$. aff. abyssalis are $4.16 \mathrm{~cm} . \mathrm{s}^{-1} \pm 1.8 \mathrm{SD}$ and $4.02 \mathrm{~cm} . \mathrm{s}^{-1} \pm 0.87$ SD respectively which, given slightly smaller body lengths than E. gryllus, makes them comparable to these abyssal scavengers despite these measurements being made at nearly twice the depth.

Pirlot (1936) reported that among the deep sea species of the Dutch 'Siboga' expedition $(1899-1900)$ there were a group of amphipods thought to occur directly on the sediment surface. He reported the most striking characteristic of this group was their long and slender bodies, often with dorsal projections with very long and slender appendages comparable to other amphipods such as Lepechinella cuvvispinosa (Lepechinellidae) and Rhachotropis sibogae (Eusiridae). Princaxelia appears to fit the description of Pirlot (1936); long and slender bodies and appendages, and dorsal projections. The in situ observations reported here confirm Pirlot's assumption that these types of amphipods sit directly on the sediment surface.

In addition to the observations of Princaxelia amphipods reported here there is also an important point of where they have not been found. Using identical equipment, observations have been made at five stations in the north-west Pacific (Marianas, Japan and Izu-Ogasawara Trenches between

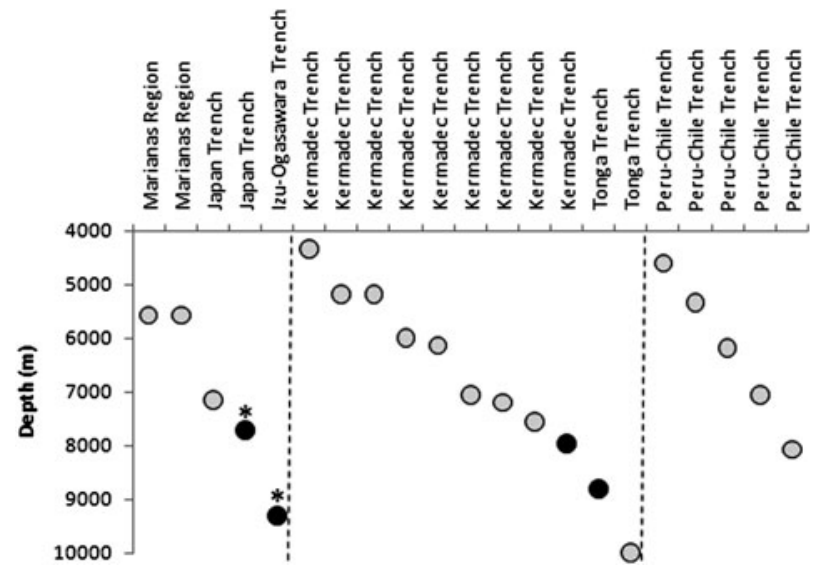

Fig. 8. Presence (black dots) and absence (grey dots) of Princaxelia amphipods from the baited camera 'Hadal-Lander' in the north-west, south-west and south-east Pacific Trenches. *, indicates depths where specimens were simultaneously recovered in baited traps.

5575 and $9316 \mathrm{~m}$ ), eleven deployments in the south-west Pacific (Kermadec and Tonga Trenches; 4329 to $9726 \mathrm{~m}$ ) and five in the south-east Pacific (Peru-Chile Trench; 4602 to $8075 \mathrm{~m}$ ) (Figure 8). These other deployments comprised thousands of still images and hours of video footage and other than the observations reported here, no other Princaxelia amphipods were seen. These reports of both presence and absence, particularly from abyssal depths indicate that the Princaxelia is primarily an endemic hadal genus.

Whilst in situ observations of amphipods via baited cameras have occurred before (e.g. Smith \& Baldwin, 1982; Laver et al., 1985), these have always focused on scavenging lysianassoids. Even though Pardaliscidae are known to be conspicuous members of the abyssal and hadal environments (e.g. Dahl, 1959; Kamenskaya, 1984), these are the first in situ observations. Future studies will show if the observed impressive swimming and moving abilities are also true for other genera of Pardaliscidae. We assume that these are less family driven, but developed as adaptation to the life in the deep sea. With further study, genera of other families, e.g. Lepechinella (Lepechinellidae) or Rhachotropis (Eusiridae), may reveal similar adaptations.

The Princaxelia amphipods are a rare genus typically found at hadal depths. They are readily attracted to bait using assumed olfactory senses whereupon they prey on small scavenging amphipods. Their attendance at bait is regular and in some instances is gregarious. Prey is caught using rapid forward propulsion whereupon the prey is restricted by the large maxilliped and strong gnathopods. Physiologically they do not appear inhibited by the extreme ambient hydrostatic pressure, exhibiting impressive mobility and flexibility in swimming.

\section{ACKNDWLEDGEMENTS}

We thank the chief scientists, crew and company of the RV 'Hakuho-Maru' cruise to the Japan Trench (KH-08-03), the RV 'Tansei-Maru' cruise to the Izu-Ogasawara (KT-09-03) and the FS 'Sonne' cruise to the Kermadec and Tonga Trenches (SO197). Dr Tomislav Karanovic (University of 
Seoul) helped with Russian translations and took the photographs in Figure 1. We thank Dr Niamh Kilgallen (NIWA, New Zealand) and Dr Tammy Horton (NOC, UK) for sorting the trap samples. The second author A.N.L. was funded by the NIWA Capability project CF113353. The HADEEP project was funded jointly by the Nippon Foundation (Japan) and the Natural Environmental Research Council (NERC; UK).

\section{REFERENCES}

Dahl E. (1959) Amphipoda from depths exceeding $6000 \mathrm{~m}$. Galathea Report 1, 211-240.

Fujii T., Jamieson A.J., Solan M., Bagley P.M. and Priede I.G. (2010) A large aggregation of liparids at $7703 \mathrm{~m}$ depth and a reappraisal of the abundance and diversity of hadal fish. BioScience 60, 506-515.

Jamieson A.J., Solan M. and Fujii T. (2009a) Imaging deep-sea life beyond the abyssal zone. Sea Technology 50, 41-46.

Jamieson A.J., Fujii T., Solan M., Matsumoto A.K., Bagley P.M. and Priede I.G. (2009b) Liparid and macrourid fishes of the hadal zone: in situ observations of activity and feeding behaviour. Proceedings of the Royal Society B 276, 1037-1045.

Jamieson A.J., Fujii T., Solan M., Matsumoto A.K., Bagley P.M. and Priede I.G. (2009c) First findings of decapod crustacea in the hadalzone. Deep-Sea Research 1 56, 641-647.

Kaartvedt S., Van Dover C.L., Mullineaux L.S. Wiebe P.H. and Bollen S.M. (1994) Amphipods on a deep-sea hydrothermal treadmill. Deep-Sea Research I 41, 179-195.

Kamenskaya O.E. (1977) Two new species of ultraabyssal amphipods from Yap Trench. Akademia Nauk SSSR 108, 105-114.

Kamenskaya O.E. (1981) Ultraabyssal (hadal) amphipods from the trenches of the Pacific Ocean. P.P. Shirshov Institute of Oceanology Academy of Sciences of the USSR Moscow 117218, USSR, pp. 40-44

Kamenskaya O.E. (1984) Ecological classification of deep-sea amphipods. Trudy Institute of Oceanology, Russia 119, 154-160. [In Russian.]

Kamenskaya O.E. (1995) Gammaridean amphipods from hadal trenches of the Pacific Ocean. Polskie Arhiwum Hydrobiologii 42, 327-334.
Laver M.B., Olsson M.S., Edelman J.L. and Smith K.L. (1985) Swimming rates of scavenging deep-sea amphipods recorded with a free-vehicle video camera. Deep-Sea Research 32, 1135-1142.

Lörz A-N. (2010) Trench treasures: the genus Princaxelia (Pardaliscidae, Amphipoda). Zoologica Baetica 21, 65-84.

Pirlot J.M. (1936) Les amphipodes de l'expédition du Siboga. Deuxième Partie. Les amphipodes gammarides. II. -Les amphipodes de la Mer Profonde. 3. Addendum et partie générale. III. Les amphipodes littoraux. 1. Lysianassidae, Ampeliscidae, Leucothoidae, Stenothoidae, Phliantidae, Colomastigidae, Ochlesidae, Liljeborgiidae, Oedicerotidae, Synopiidae, Eusiridae, Gammaridae. Siboga-Expeditie $28 \mathrm{e}, 237-328$.

Sainte-Marie B. (1986) Feeding and swimming of lysianassid amphipods in a shallow cold-water bay. Marine Biology 91, 219-229.

Sainte-Marie B. and Hargrave B.T. (1987) Estimation of scavenger abundance and distance of attraction to bait. Marine Biology 94, 431-443.

Saunders P.M. (1981) Practical conversion of pressure to depth. Journal of Physical Oceanography 11, 573-574.

Smith K.L. and Baldwin R.J. (1982) Scavenging deep-sea amphipods: effects of food odor on oxygen consumption and a proposed metabolic strategy. Marine Biology 68, 287-298.

Stebbing T.R.R. (1888) Report on the Amphipoda collected by H.M.S. Challenger during the years 1873-1876. Report on the Scientific Results of the Voyage of H.M.S. Challenger during the years 1873-76, Zoology 29, 1-1737, pls 1-210.

Stephensen K. (1931) The Danish Ingolf-expedition. Crustacea Malacostraca VII (AMPHIPODA III). 3, pp. 180-290.

and

Takeuchi I. and Watanabe K. (1998) Respiration rate and swimming speed of the necrophagous amphipod Eurythenes gryllus from Antarctic deep waters. Marine Ecology Progress Series 163, 285-288.

\section{Correspondence should be addressed to:}

A.J. Jamieson

Oceanlab, Institute of Biological and Environmental Science University of Aberdeen

Main Street, Newburgh, Aberdeenshire

UK AB41 6AA

email: a.jamieson@abdn.ac.uk 